\title{
Numerical study of semi-elliptical cracks in the critical position of pipe elbow
}

\author{
Bassam Gamal Nasser Muthanna \\ LRM, Hassiba Benbouali University of Chlef, Faculty of Technology, Esalem City, 02000, Chlef, Algeria \\ b.muthanna@univ-chlef.dr.
}

Omar Bouledroua

Sonatrach/Direction Centrale Recherche et Développement, Avenue du 1er Novembre, 35000 Boumerdès, Algérie

Hassiba Benbouali University of Chlef, LPTPM, Esalem City, 02000, Chlef, Algeria

o.bouledroua@sonatrach.dz,o.bouledroua@univ-chlef.dz

Madjid Meriem-Benziane

LRM, Hassiba Benbouali University of Chlef, Esalem City, 02000, Chlef, Algeria

mbmadid2001@yahoo.fr

Mohammed Hadj-Meliani ${ }^{1,2}$, Guy Pluvinage ${ }^{2}$

${ }^{1}$ LPTPM, Hassiba Benbouali University of Chlef, Esalem City, 02000, Chlef, Algeria

${ }^{2}$ LE3M, University of Lorraine, Illea of Saulcy, 57045 Metz, France

m.badjmeliani@univ-chlef.dz,plwinage@sfr.fr

Rami Khalid Suleiman

Center of Research Excellence in Corrosion, King Fabd University of Petroleum and Minerals (KFUPM), Dhahran 31261, Saudi Arabia

ramismob@kefupm.edu.sa

ABSTRACT. Pipelines are considered as a major tool to transport hydrocarbons due to its important role in transporting fluids taking into account the operating conditions. Despite the importance of the elbow which considered as a critical part in the pipelines, the repeated failures and defects became a dangerous and enormously costly issue. In this numerical study, the Fluid-Structure Interaction (FSI) analysis was carried out using Ansys software. This work is divided into four main parts: the first part focused on studying and comparing the effect of bending radius of pipe elbow on the maximum of Von-Mises stress values for each radius with the yield stress of the steel of the pipe. The second part focused on the creation of a semielliptical crack for different locations along the elbow angles to show the critical position compared to the stress intensity factors. In the third part, the

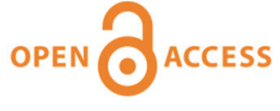

Citation: Muthanna, B. G. N., Bouledroua, O., Meriem-Benziane, M., Hadj Meliani, M., Pluvinage, G., Suleiman, R. K., Numerical study of semi-elliptical cracks in the critical position of pipe elbow, Frattura ed Integrità Strutturale, 49 (2019) 463-477.

Received: 14.01.2019

Accepted: 13.05.2019

Published: 01.07.2019

Copyright: (C) 2019 This is an open access article under the terms of the CC-BY 4.0, which permits unrestricted use, distribution, 
semi-elliptical crack angle orientation was studied at the critical position to estimate the critical angle. In the last part, the failure assessment diagram

and reproduction in any medium, provided the original author and source are credited. (FAD) was used to show the critical crack depth ratios at a critical position and a critical angle.

KEYwORDS. Elbow, Pipe, Semi-elliptical crack, Stress Intensity Factors (SIFs), Failure Assessment Diagram (FAD).

\section{INTRODUCTION}

$\mathrm{P}$ ipelines are very important tool to transport hydrocarbons with high safety properties over long distances [1-3]. Indeed, the piping systems including the elbows are subjected to severe factors which may menace the integrity and safety of the pipe [4-5]. Due to the importance of elbows in the petroleum industries including their geometry and location, they are considered to be as critical parts in piping systems [6-7]. Due to their geometry, stress amplification occurs which promote failure and leak. Moreover, their stiffness is less in comparison with straight pipes having the same crosssection and material properties, inducing significantly higher stresses and deformations which may lead to failure. The corrosion phenomenon of elbow is one of the major damage problems in the energy transportation due to unsuitable factors such as fluid nature, operating conditions and the material of pipeline [8-11]. This situation may affect the energy transport significantly and increase the possibility of corrosion to occur. Many authors have studied the interaction between fluid and solid or solid-solid for two types of damage such as erosion and corrosion of steel pipelines [12-15]. El-Gammal et al. [16] have presented the flow accelerated corrosion of a 90-degree elbow by computational fluid dynamics (CFD) simulation. They have proved that the wear maximum value at elbow extrados is approximately $37 \%$ less than the maximum value along intrados. Muthanna et al. [17] have investigated the erosion corrosion in the internal surface of pipe elbow. They have found that the small sand particles and the attack of fluid flow on critical positions were responsible for this serious problem. Tian et al. [18] have examined the effect of flow velocity on the corrosion behavior of AZ91D magnesium alloy at pipe elbow to analyze the interaction between fluid and internal wall of elbow in the critical zones. Their results have showed that the corrosion rate augment with the increasing of flow velocity. The erosion-corrosion phenomenon occurs in difficult situations where the interaction is a complex field which leads to make a degradation for wall thickness of pipeline steels [19-21]. Barros et al. [22] have studied the repairing of a real corrosion defect by composite sleeve at welded joints. Moreover, many researchers [23-26] have studied the circumferential stress in the pipe elbow by analytical models, numerical methods and/or experimental tests. They proved that the maximal circumferential stress located in the intrados section of elbow. In addition, other authors [27-31] have used the Failure Assessment Diagram (FAD) to classify the grade of safety of pipelines or elbows.

This work aimed to study the safety of a pipe elbow under the effect of gas pressure with change of radius bending, crack position, crack angle orientation, and semi elliptical crack depth ratios. To evaluate the influence of the flow in the internal wall of the critical position of a pipe elbow, a semi-elliptic crack was used. The results of the stress intensity factor (mode I) can give the solutions to avoid corrosion phenomena due to the nature of liquid and the material quality of pipe elbow. This study was conducted to improve the durability and the performance of elbow steel.

\section{NUMERICAL STUDY AND SOFTWARE ANALYSIS}

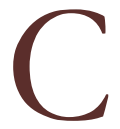

orrosion and erosion induce the most common defects occurring to pipeline. An example for a corrosion case of a pipeline is shown in Fig. 1. We have performed a numerical study in order to understand, relief and avoid the occurrence of such corrosion problems as much as possible. In this numerical study, the interaction between elbow and natural gas analyses was carried out by ANSYS software [32]. 90 pipe elbow made of API X52 steel was investigated and the pipe and its dimensions are shown in Fig. 1. Tab. 1 and 2 present the chemical composition and mechanical properties of API 5L X52 pipeline steel, respectively. Tab. 3 shows the parameters of the natural gas flow properties.

The geometry of the elbow is shown in Fig. $1 \mathrm{~b}$. Dimensions are as follow: internal radius $\mathrm{R}_{\mathrm{i}}=298.45 \mathrm{~mm}$, wall thickness $\mathrm{t}=$ $12.7 \mathrm{~mm}$ and the length $\mathrm{L}=1000 \mathrm{~mm}$. $\rho$ is the elbow bending radius radius. 

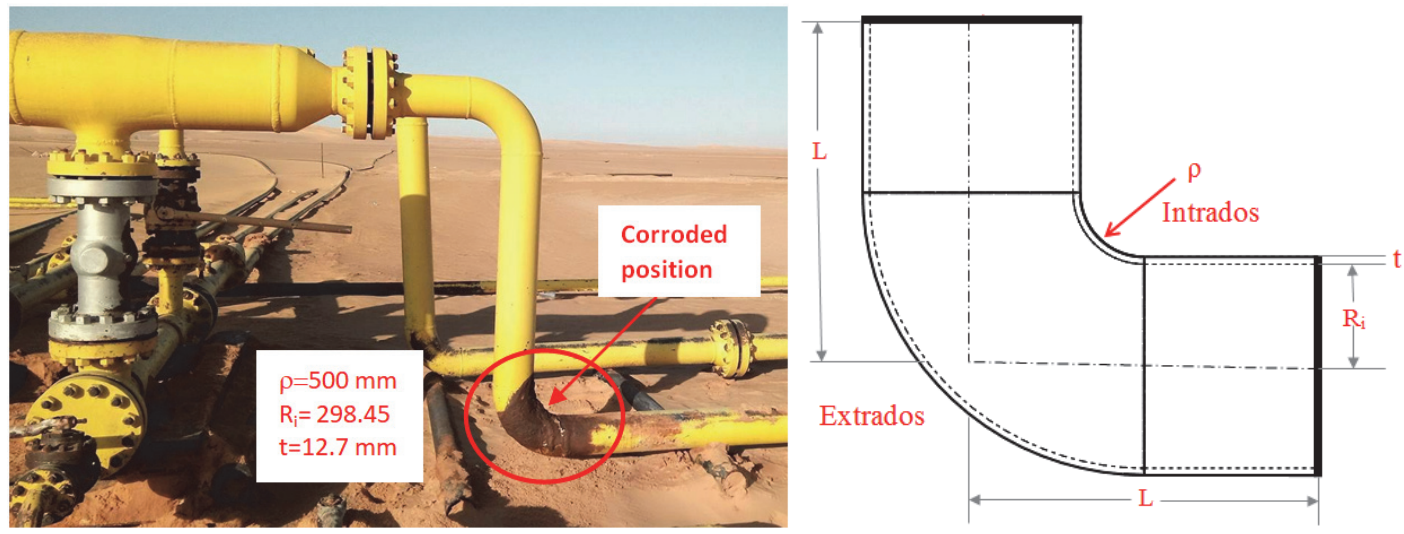

Figure 1: API X52 pipeline steel (a) an example of real corroded steel (b) Geometrical model of the pipe elbow.

\begin{tabular}{ccccccccc}
\hline $\mathrm{C}$ & $\mathrm{Si}$ & $\mathrm{Mn}$ & $\mathrm{P}$ & $\mathrm{S}$ & $\mathrm{Cr}$ & $\mathrm{Ni}$ & $\mathrm{Mo}$ & $\mathrm{Al}$ \\
\hline 0.204 & 0.342 & 1.79 & 0023 & 0.0083 & 0.0474 & 0.0367 & 0.0067 & 0.0335 \\
\hline $\mathrm{Co}$ & $\mathrm{Cu}$ & $\mathrm{Nb}$ & $\mathrm{Ti}$ & $\mathrm{V}$ & $\mathrm{W}$ & $\mathrm{Pb}$ & $\mathrm{B}$ & $\mathrm{Fe}$ \\
\hline 0.0030 & 0.0648 & 0.0024 & 0.0033 & 0.0041 & $<0.0050$ & $<0.0010$ & 0.0055 & 97.4 \\
\hline
\end{tabular}

Table 1: Chemical composition of the elbow steel.

\begin{tabular}{cccc}
\hline $\begin{array}{c}\text { Yield Strength } \\
(\mathrm{MPa})\end{array}$ & $\begin{array}{c}\text { Ultimate Strength } \\
(\mathrm{MPa})\end{array}$ & $\begin{array}{c}\text { Elongation } \\
\text { at failure } \mathrm{A} \%\end{array}$ & $\begin{array}{c}\text { Fracture toughness } \\
\mathrm{K}_{\mathrm{IC}}(\mathrm{MPa} \sqrt{\mathrm{m}})\end{array}$ \\
410 & 528 & 32 & 116.6 \\
\hline
\end{tabular}

Table 2: Tensile properties of API 5L X52 pipe elbow steel.

\begin{tabular}{cccc}
\hline $\begin{array}{c}\text { Gas flow } \\
\left.\text { (millions } \mathrm{m}^{3} / \text { day }\right)\end{array}$ & $\begin{array}{c}\text { Operating pressure } \\
(\mathrm{MPa})\end{array}$ & $\begin{array}{c}\text { Operating temperature } \\
\left({ }^{\circ} \mathrm{C}\right)\end{array}$ & Density \\
$2.6-3$ & 7 & 52 & 0.806 \\
\hline
\end{tabular}

Table3: Parameters of natural gas flow.

\section{RESULTS AND DISCUSSIONS}

$\mathrm{D}$ ue to the complexities of carrying out an experimental study, we have used a numerical software in order to understand the interaction between elbow and natural gas. In particular, we have used ANSYS Workbench software with the computational fluid dynamics Software (CFD section). A steady state gas flow analysis and pressure distributions were carried out. These pressures across the elbow were obtained by the importation of the other section called APDL (Ansys Parametric Design Language) where the Fig. 2 illustrates the methodology of numerical steps. First of all, elbow radius was applied progressively in order to show the stress. At stabilization, the study of stress distributions along elbow curvature under gas pressure of $7 \mathrm{MPa}$ was conducted in order to get the critical position defined as the position of maximum stress.

At this critical position, a semi-elliptical crack was introduced and its orientation $\theta$ effect was studied in order to get the critical crack angle. This will create different semi-elliptical crack depths $(a / t)$ in the range of 0.1 to 0.8 ; where "a" is the crack depth and " $\mathrm{t}$ " is the pipe elbow thickness. Failure assessment diagram (FAD) curve was used to evaluate the critical crack depth ratios at a critical position and a critical angle. 


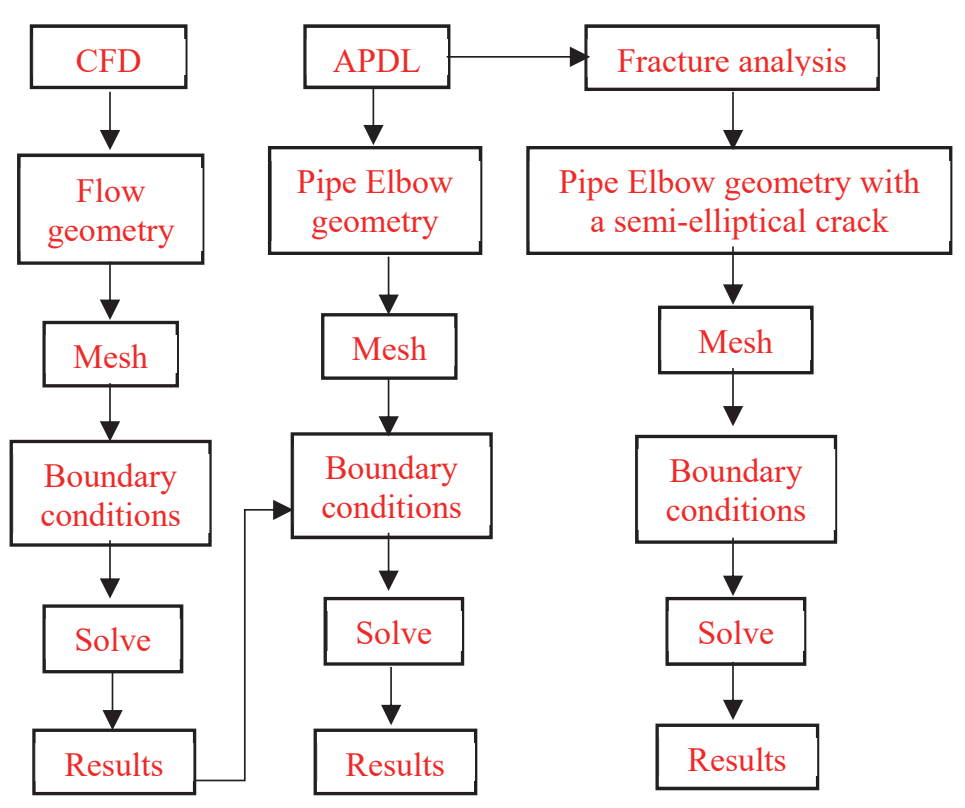

Figure 2: Schematic description for numerical methodology

\section{Effect of elbow radius}

In order to find out the adequacy of different finite element types and the sensitivity of our models to different parameters, different steps were studied by extracting their critical positions and applying boundary conditions with suitable mesh to get better results. Fig. 3 illustrates the elbow geometry, meshing and boundaries conditions of our model. Pressure distributions were applied in the internal surface of pipe elbow.

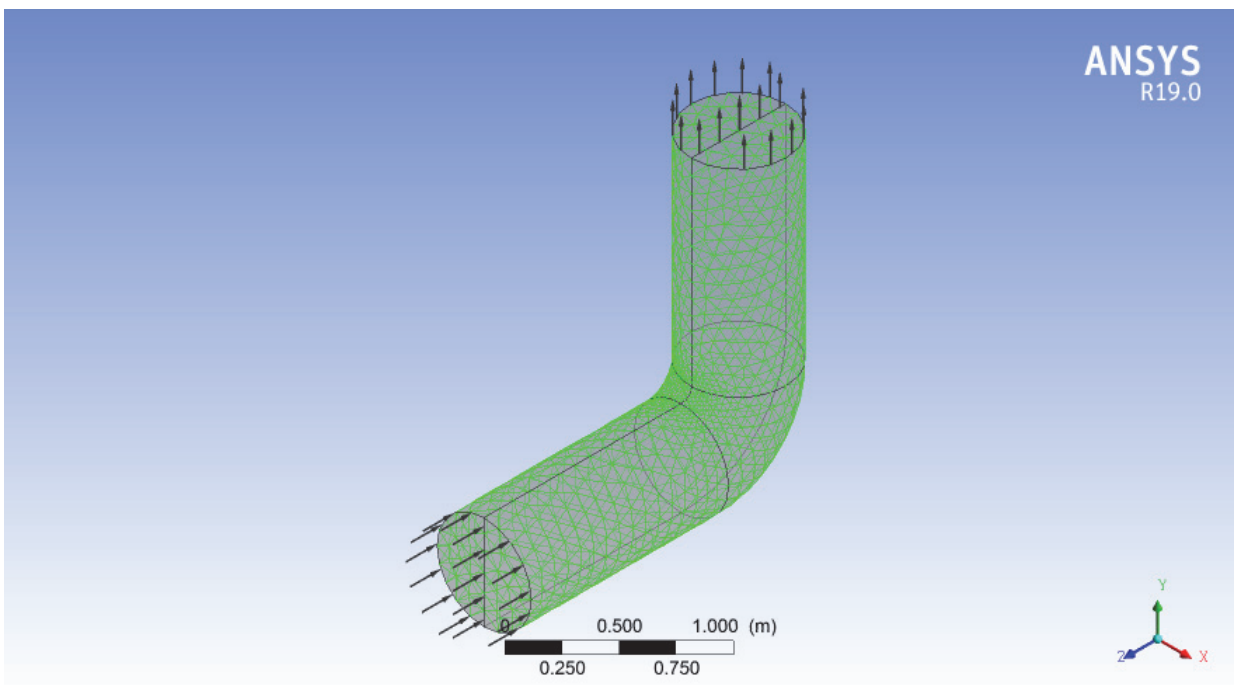

Figure 3: Geometry, meshing and boundaries conditions of elbow model.

In order to analyze the effect of the cracked elbow on the safety of piping system at critical zones, the radius bending was taken into our consideration as it plays an important role in the security and assessment for pipeline failure where the critical zones are affected by the interaction fluid/ structure including elbow geometry. Figs. (4-6) show the distribution of pressure, velocity and Von-Mises stress along the pipe elbows, respectively.

The Effect of elbow radius was investigated in order to obtain the radius value at which the stress is stabilized. The change in the elbow radius leads to change the behavior flow including the maximum stress and therefore to security and defect assessment of pipeline as shown in Fig. 7. 


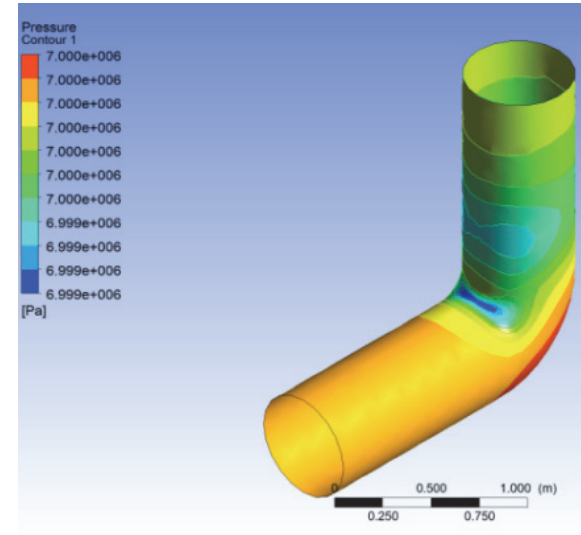

(a)

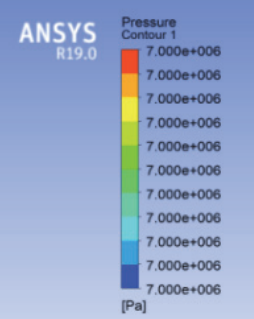

人

Figure 4: Pressure distribution along the elbow for (a) $\rho=50 \mathrm{~mm}$ and (b) $\rho=500 \mathrm{~mm}$.

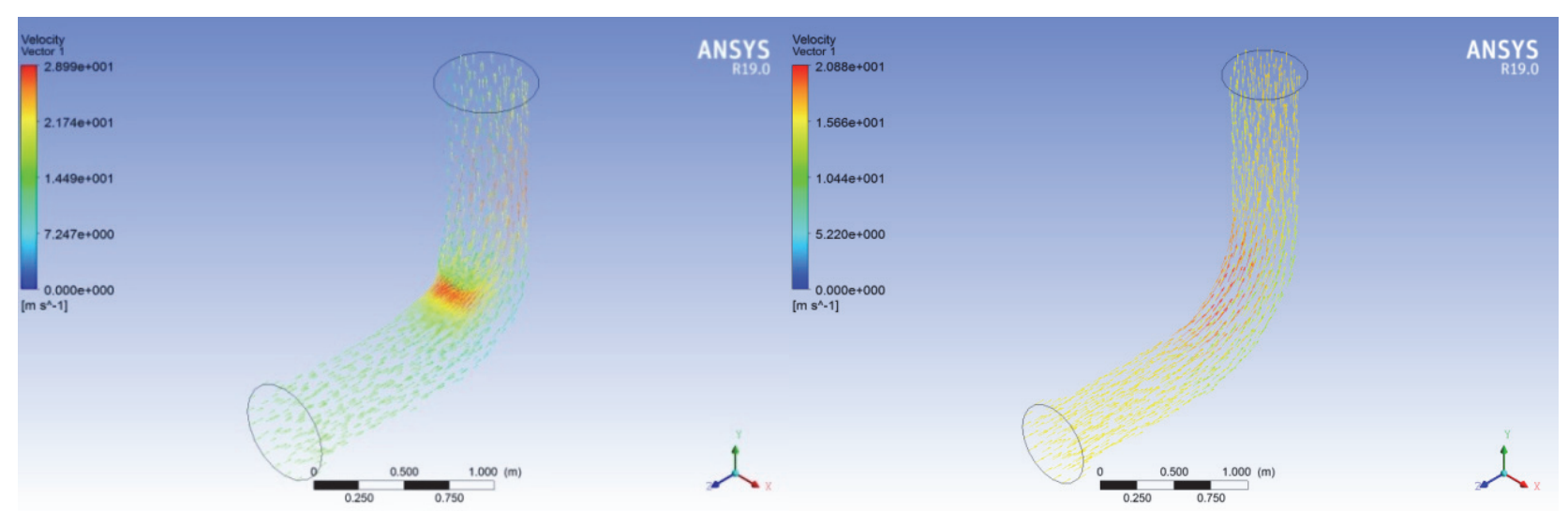

(a)

(b)

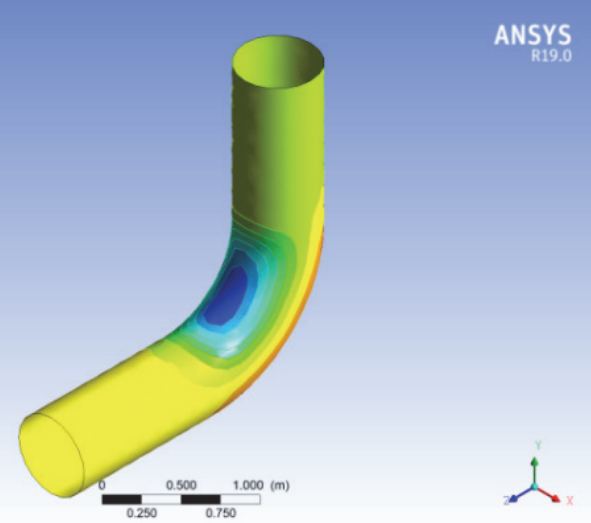

(b)

Figure 5: Velocity distribution along elbow for (a) $\rho=50 \mathrm{~mm}$, (b) $\rho=500 \mathrm{~mm}$.

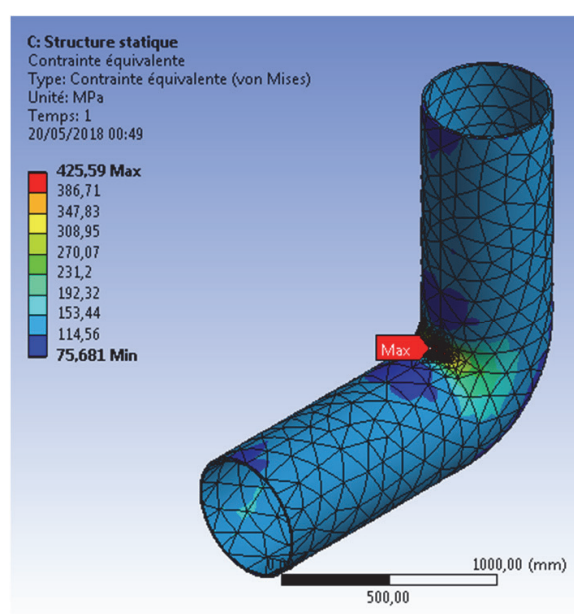

(a)

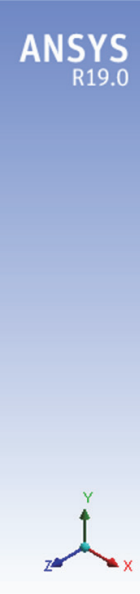

C: Structure statique
Contrainte équivalente

Type: Contrainte équivalente (von Mises)

Unité: MPa

06/06/2018 15:20

198,96 Max

189,55
180,14
170,73
161,31

170,33
161,31
151,9

$\begin{aligned} &-151,9 \\ &-142,49 \\ &- 133,08\end{aligned}$

133,08
$-123,67$

123,67
$\mathbf{1 1 4 , 2 6}$ Min

(n)

(b)

Figure 6: Von-Mises stress distribution along pipe elbow for (a) $\rho=50 \mathrm{~mm}$, and (b) $\rho=500 \mathrm{~mm}$ 


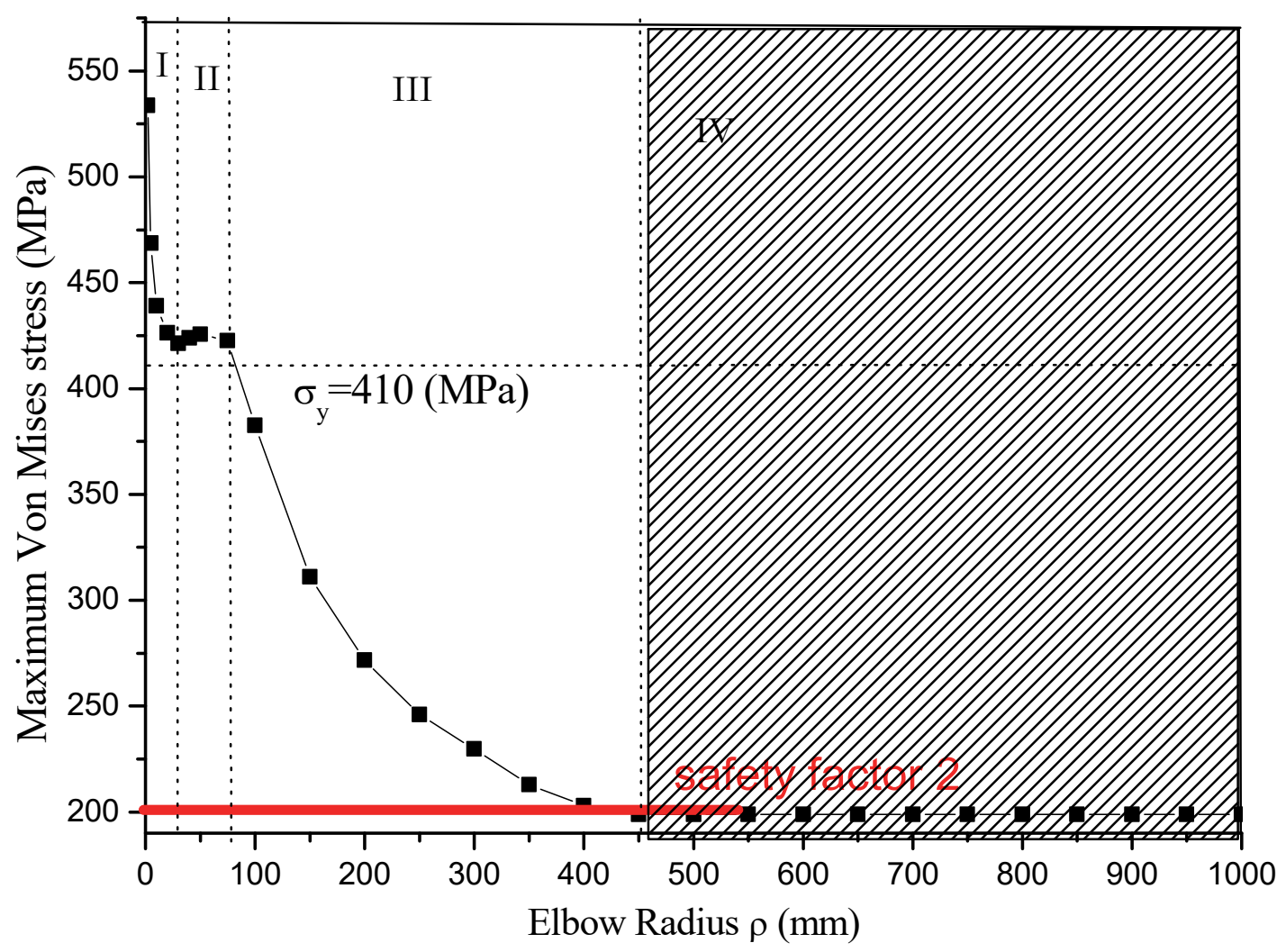

Figure 7: Effect of elbow radius on maximum Von Mises Stress.

\begin{tabular}{ccccc}
\hline radius & $\rho<25$ & $25<\rho<85$ & $85<\rho<450$ & $\rho>450$ \\
Admissibility & no $\left(\sigma_{\theta \theta}>\sigma_{\mathrm{y}}\right)$ & no $\left(\sigma_{\theta \theta} \sim \sigma_{\mathrm{y}}\right)$ & No $\left(\mathrm{F}_{\mathrm{s}}<2\right)$ & Yes $\left(\mathrm{F}_{\mathrm{s}}>2\right)$ \\
Stress evolution & Decrease & Stabilization & Decrease & Stabilization \\
\hline
\end{tabular}

Table 4: Evaluation of the effect of elbow radius on maximum Von Mises Stress.

The effect of elbow radius was also examined according to the maximal values of Von-Mises stress as it shown in Fig. 7. Von Mises stress evolution can be divided into four zones as indicated in Tab. 4. The admissible elbow radius refers to the value of Yield strength of API X52 pipeline steel which is equal to $410 \mathrm{MPa}$ and the traditional safety factor taken as $\mathrm{F}_{\mathrm{s}}=$ 2. Any bending radius leading to a maximum stress greater than $410 \mathrm{MPa}$ divided by the safety factor is not acceptable for industrial service. As a real case (Fig. 1a), a value of $500 \mathrm{~mm}$ of elbow radius was taken in our investigation. For this case: the stress amplification due to the presence of elbow is $\mathrm{k}_{\mathrm{t}}=1.2$.

\section{Critical position along elbow}

ANSYS simulation offers a good way to increase the pipeline efficiency and to prevent the occurrence of corrosion. The presence of high stress in elbow can be considered as a crucial problem depending on elbow angle. Critical zone presented as a red zone in Fig. 6 that is resulting from the internal natural gas pressure. Fig. 8 presents the corresponding distribution of different stresses (Von-Mises, normal stress and principal stress).

Fig. 8 indicates that the maximum value of Von-Mises stress is $198.96 \mathrm{MPa}$. Normal stress $\sigma_{\mathrm{xx}}$ and principal stress $\sigma_{\theta \theta}$ have the same value equal to $219.56 \mathrm{MPa}$. The maximum stress criterion apply to the 3 different stresses gives a maximum stress localization in the same node with an angle $\alpha=72^{\circ}$. In the next part, a semi-elliptical crack is introduced with in different angular position along the intrados of elbow $\left(\alpha=5^{\circ}\right.$ to $\left.\alpha=85^{\circ}\right) ; \alpha$ is defined in Fig. 9. The semi-elliptical crack has a relative depth ratio $\mathrm{a} / \mathrm{t}=0.5$ and $\mathrm{a} / \mathrm{c}=0.5$. In the next figures, the stress intensity factor in mode $\mathrm{I}$ as a function of crack tip angle $\phi$ is presented. 


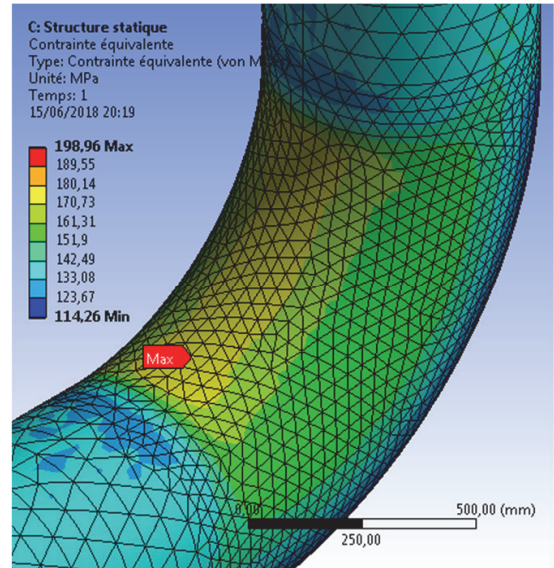

(a)

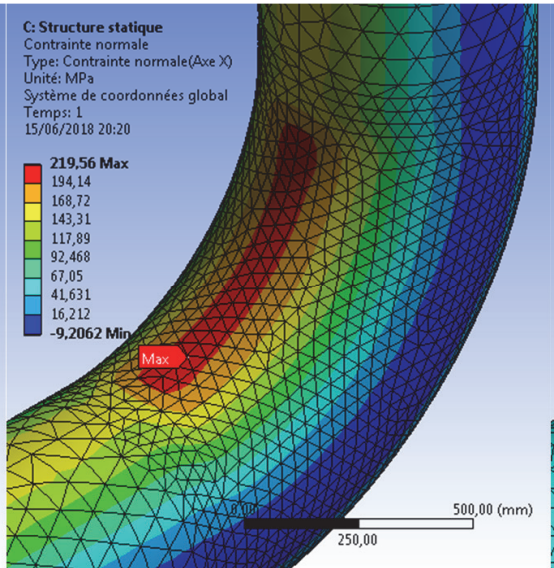

(b)

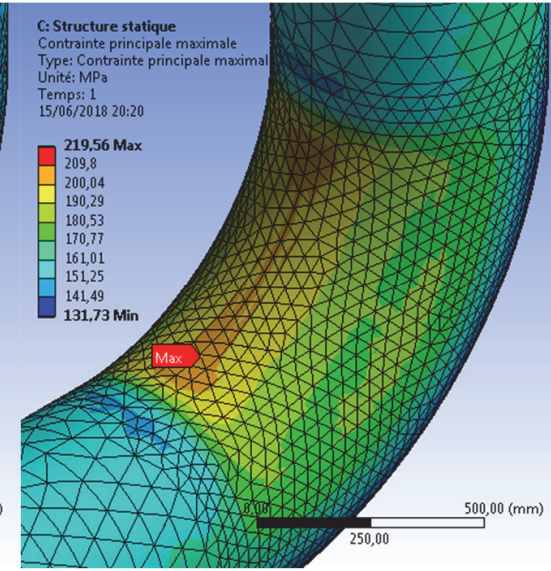

(c)

Figure 8: Stresses distribution in elbow (a) Von-Mises stress, (b) Normal stress $\sigma_{\mathrm{xx}}$ and (c) Principal stress $\sigma_{\theta \theta}$

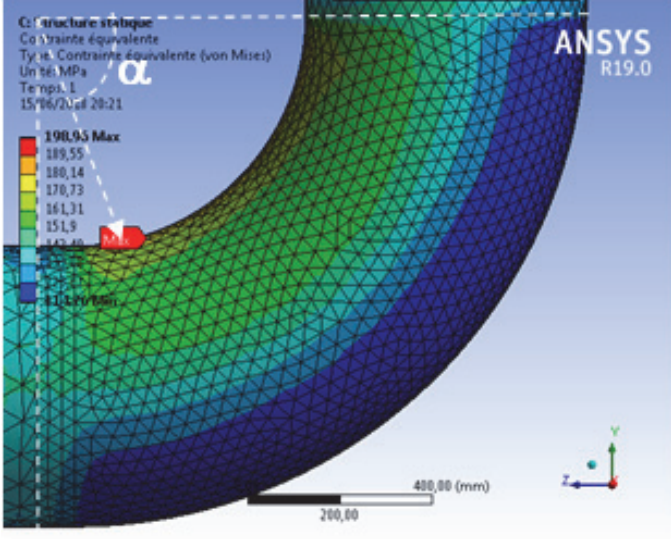

(a)

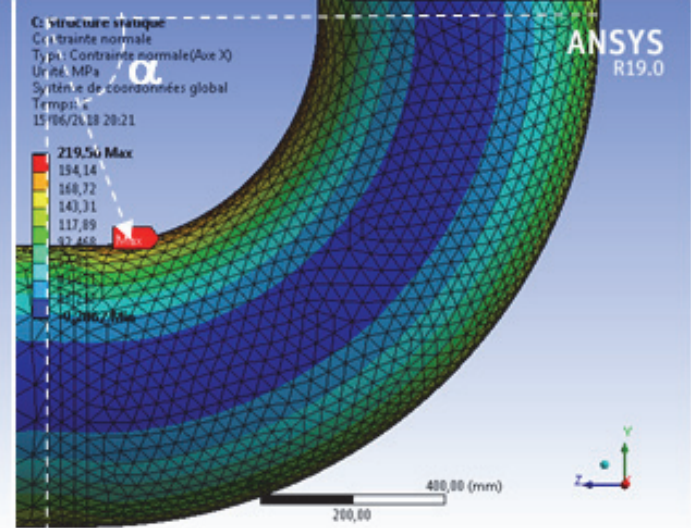

(b)

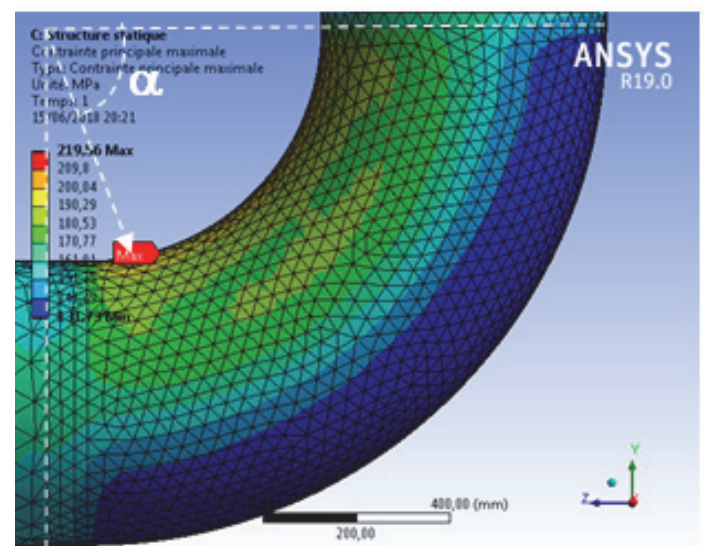

(c)

Figure 9: Maximum stresses distribution versus crack angle $\alpha$ in elbow (a) Von-Mises stress, (b) Normal stress $\sigma_{\mathrm{xx}}$ and (c) Principal stress $\sigma_{\theta \theta}$.

The original point of cracking at critical zone is one of among important reasons responsible for pipe elbow corrosion issue. Fig. 10 presents the stress intensity factor distributions in a semi-elliptical surface crack for different angular positions $\phi$ along the elbow intrados surface $(\alpha)$. Maximum mode I stress intensity factor $K_{I, \max }$ is localized at $\alpha=75^{\circ}$ and is given by the following formulae [33-36] : 


$$
k_{I M a x}=\sigma_{M a x} \cdot F \cdot \sqrt{2 \pi a}
$$

" $\sigma_{\max }$ " is the maximum applied stress, "a" is the crack depth and "F" is the geometric function which depends of crack length, aspect ratio, as well as the type of applied load.

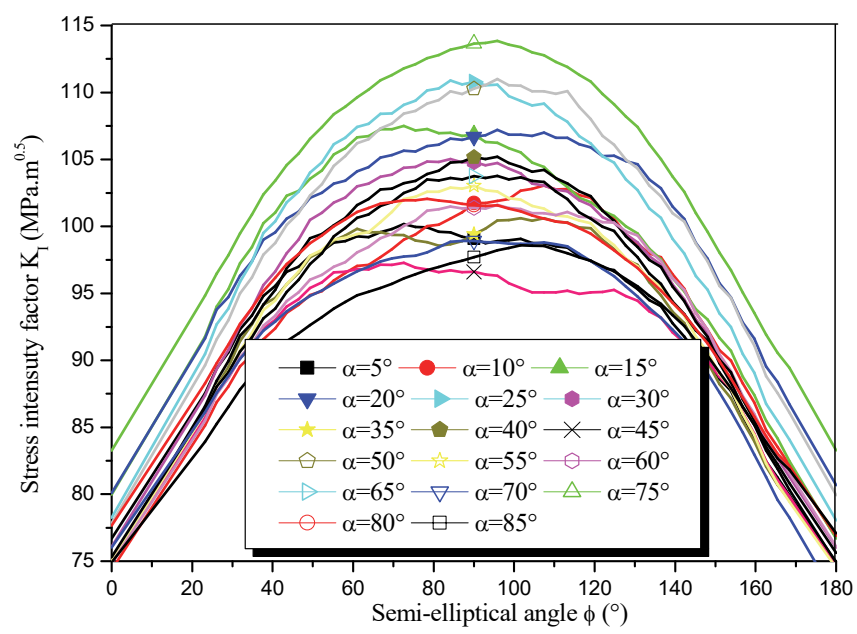

Figure 10: Mode I stress intensity factor of semi-elliptical surface crack in elbow versus angular crack $\phi$ and for different angle position $\alpha(\mathrm{a} / \mathrm{t}=0.5, \mathrm{a} / \mathrm{c}=0.5, \mathrm{P}=7 \mathrm{MPa})$.

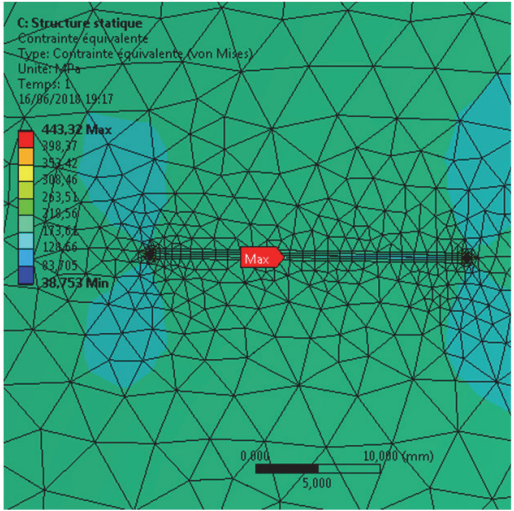

(a)

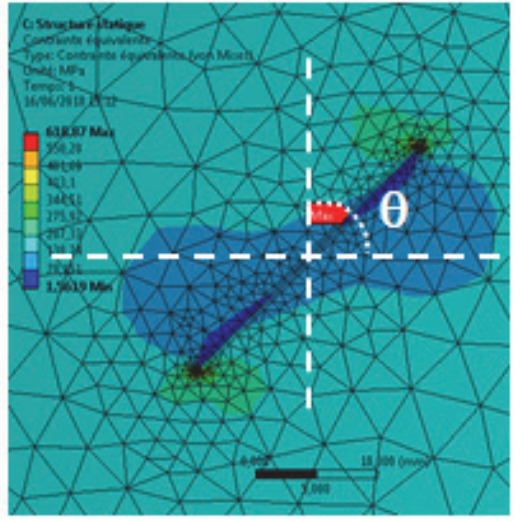

(b)

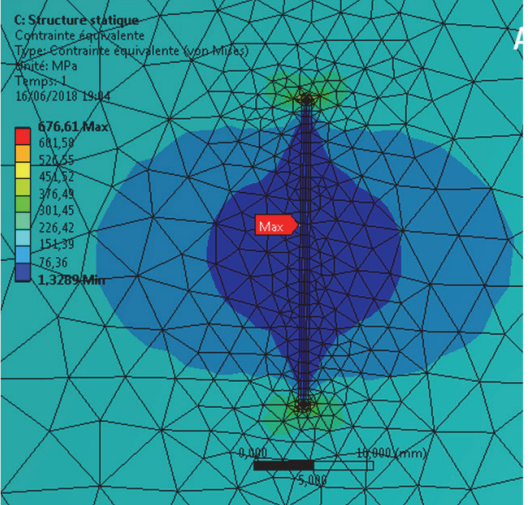

(c)

Semi-elliptical crack

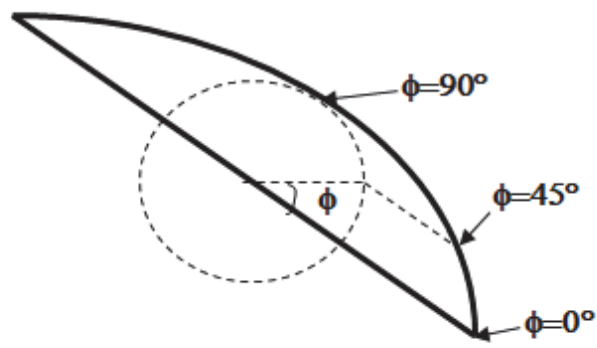

(d)

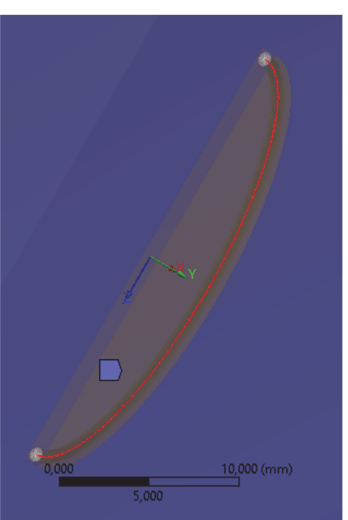

(e)

Figure 11: Stress distribution at semi-elliptical crack tip for 3 crack orientations. (a) $\theta=0^{\circ}$, (b) $\theta=45^{\circ}$ and (c) $\theta=90^{\circ}$, (d) definition of angular position $\phi$ and, (e) shape of semi elliptical crack. 
Effect of angle crack orientation on SIFs

Crack is not naturally oriented perpendicular to normal stress therefore mixed mode of loading ( $\left.\mathrm{K}_{\mathrm{I}}, \mathrm{K}_{\mathrm{II}}, \mathrm{K}_{\mathrm{III}}\right)$ is applied. In addition, elbow curvatures induce mixed mode of loading however crack orientation is $\alpha=0^{\circ}$.

Stress distributions at semi-elliptical cracks tip are illustrated in Fig. 11 for 3 crack orientations (a) $\theta=0^{\circ}$, (b) $\theta=45^{\circ}$ and (c) $\theta=90^{\circ}$; $\phi$ is the angular parameter to characterize the semi-elliptical crack front position.

Next, the stress intensity factors are considered for a critical crack orientation $\left(\alpha=75^{\circ}\right)$. The next figures present the stress intensity factors $\left(\mathrm{K}_{\mathrm{I}}, \mathrm{K}_{\mathrm{II}}, \mathrm{K}_{\mathrm{III}}\right)$ distribution of semi elliptical crack tip for different crack angular positions $(\phi)$.

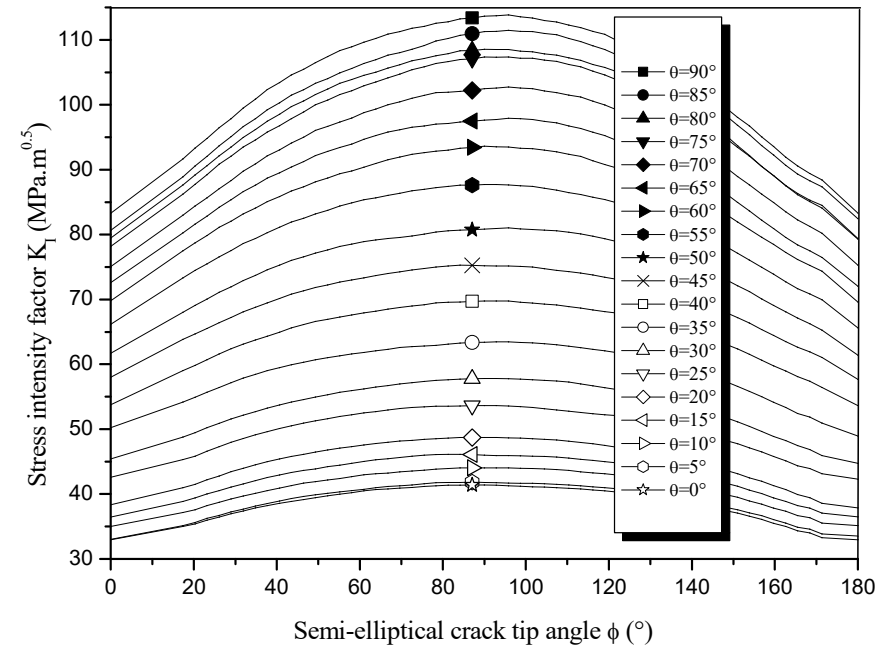

(a)

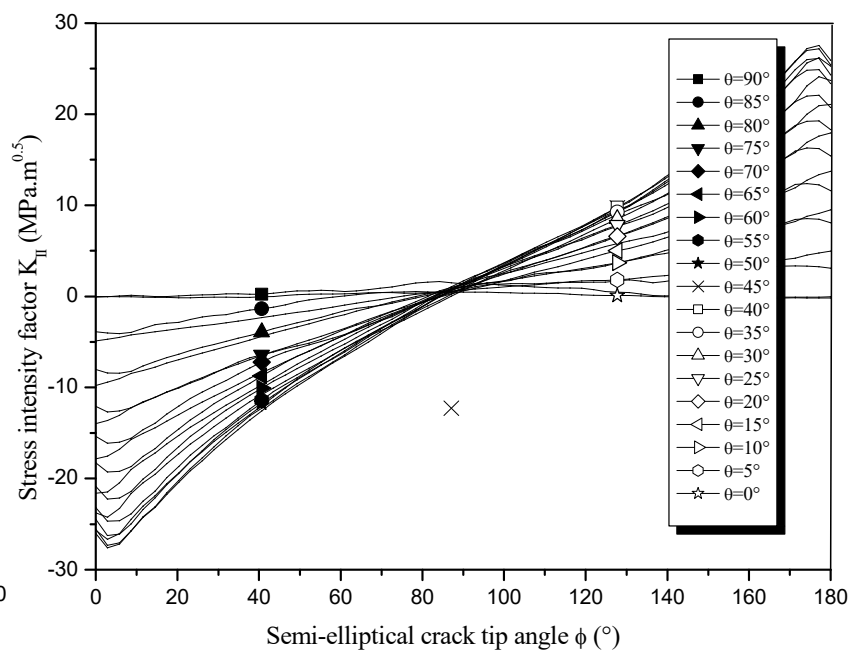

(b)

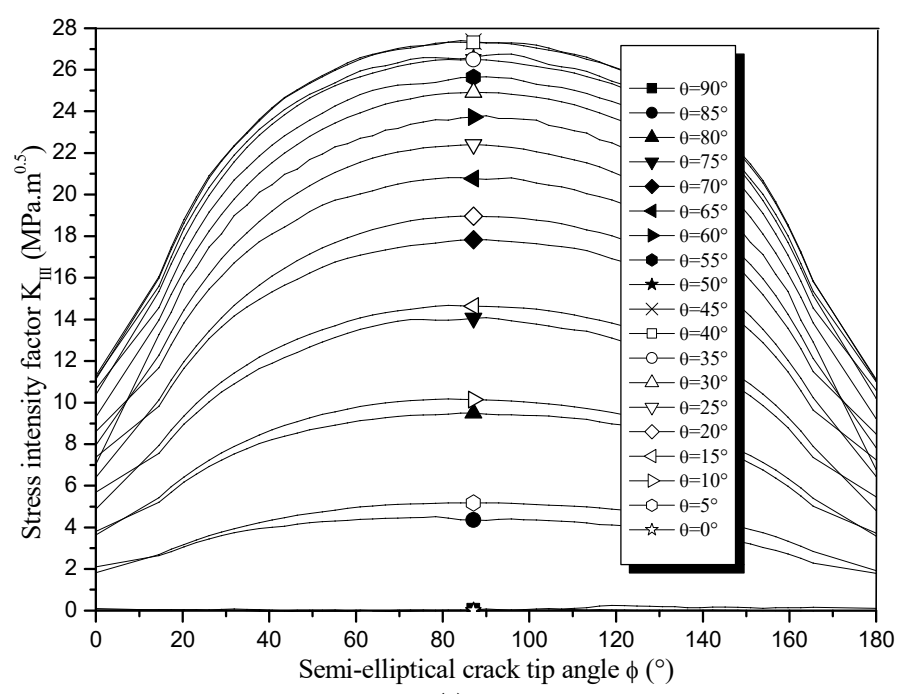

(c)

Figure 12: Stress intensity factor with different orientations of crack-tip angle (a) mode I, (b) mode II, and (c) mode III

\section{Effect of crack depth ratio on SIF}

As can be seen from SIF results, the crack is submitted to mixed mode of loading. Although the opening mode (I) is the most significant mode, still modes II and III are not negligible. Mode II is induced by longitudinal stress and mode III by pipe and elbow curvatures. Opening mode is at maximum for $\phi=90^{\circ}$. This angle point can be named as the critical angle. For this angle point, $K_{I I}$ is negligible and $K_{I I I}$ is less than $K_{I}$ of about one forth. Therefore, failure criterion is given in function of equivalent stress intensity factor which is given by:

$$
k_{e q}^{2}=K_{I}^{2}+K_{I I}^{2}+(1+v) K_{I I I}^{2}
$$


where $v$ is the Poisson's ratio. $K_{\text {eq }}$ for crack orientation angle $\theta=90^{\circ}$ is higher than $K_{\mathrm{I}}$, this indicates again that pure mode $\mathrm{I}$ is not obtained. Fig. 13 presents the equivalent stress intensity factor with the orientation $\theta$ of semi-elliptical crack in different angular position $\phi$. It shows that orientation of $90^{\circ}$ has more efficiency for elbow pipeline. The influence of relative depth ratios $(\mathrm{a} / \mathrm{t})$ changing from 0.1 to 0.8 on stress intensity factors $\left(\mathrm{K}_{\mathrm{I}}, \mathrm{K}_{\mathrm{II}}, \mathrm{K}_{\mathrm{III}}\right)$ is shown in Fig. 14 for $\mathrm{a} / \mathrm{t}=0.5$.

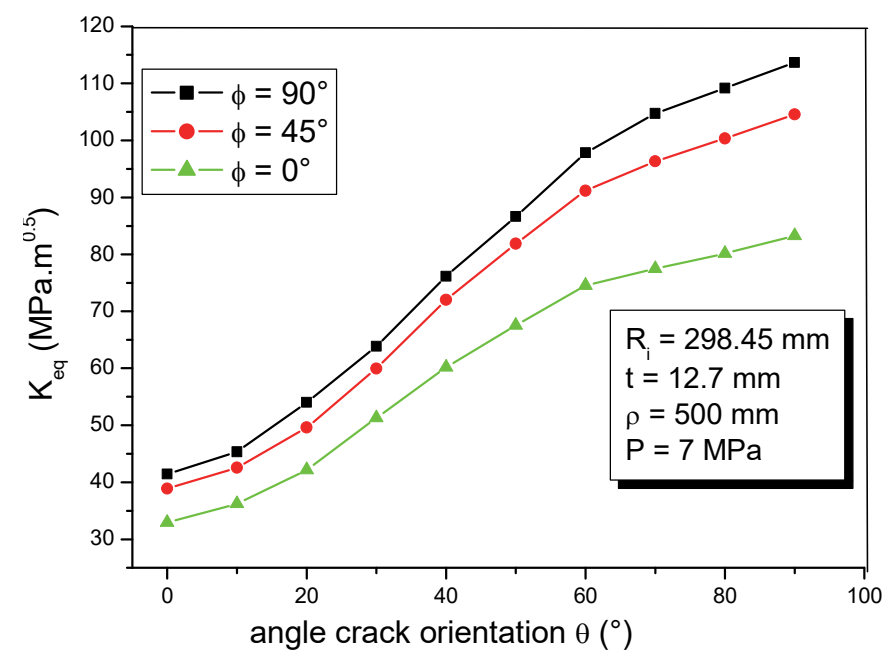

Figure 13: Equivalent stress intensity factor versus relative crack orientation for different angular position (Elbow: internal radius Ri $=$ $298.45 \mathrm{~mm}$, wall thickness $\mathrm{t}=12.7 \mathrm{~mm}$, elbow radius $\rho=500 \mathrm{~mm}, \mathrm{P}=7 \mathrm{MPa}, \mathrm{a} / \mathrm{t}=0.5)$.

Due to the concentration of energy in the critical zones in the elbow, stress intensity factors in mode $K_{\mathrm{I}}$ and $\mathrm{K}_{\mathrm{eq}}$ increase with relative crack depth ratios $(\mathrm{a} / \mathrm{t})$ as seen in Fig. 13 and 14.

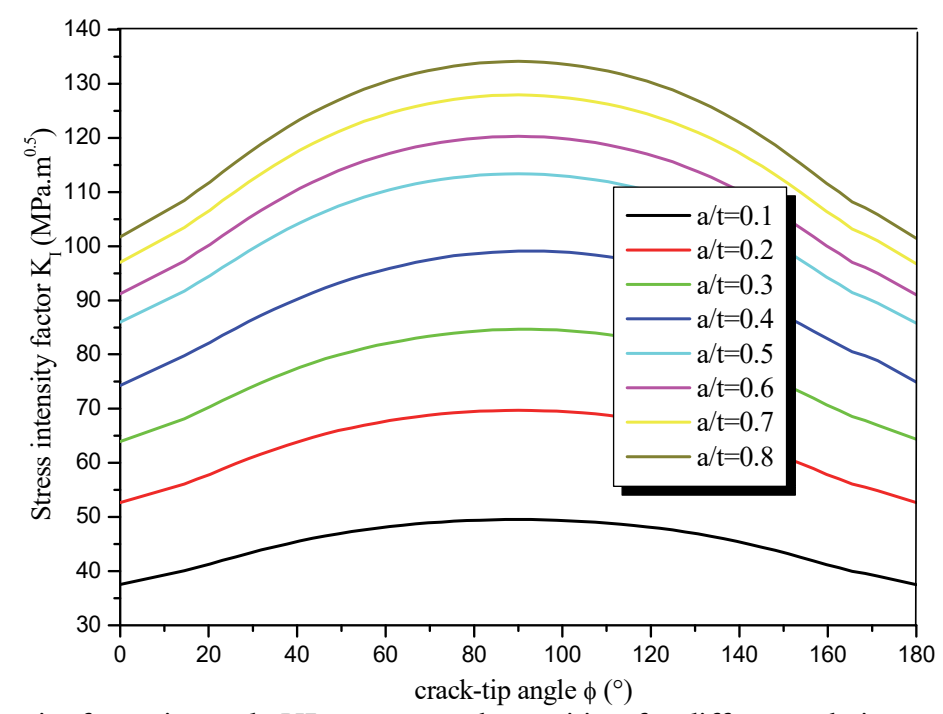

Figure14: Stress intensity factor in mode KI versus angular position for different relative crack depth ratios $(\mathrm{a} / \mathrm{t})$

The maximum equivalent stress intensity factor $\mathrm{K}_{\mathrm{eq}}$ was obtained for $\theta=90^{\circ}$ while $\mathrm{K}_{\mathrm{II}}$ is approximately negligible. Semielliptical crack with different relative depths was examined at a critical position $\left(\alpha=75^{\circ}\right)$ and a critical crack angle $\left(\theta=90^{\circ}\right)$. A failure criterion for mixed mode of loading was used:

$$
\left(\frac{K_{I \varphi}}{K_{I C}}\right)^{2}+\left(\frac{K_{I I \varphi}}{K_{I I C}}\right)^{2}+\left(\frac{K_{I I I \varphi}}{K_{I I I C}}\right)^{2}=C
$$


Failure condition is given by $\mathrm{C}=1, \mathrm{~K}_{\mathrm{I} \phi}, \mathrm{K}_{\mathrm{II} \phi}$ and $\mathrm{K}_{\mathrm{II} \phi}$ are applied in elbow at critical zone for mode I, II and III $\mathrm{K}_{\mathrm{IC}}$, $\mathrm{K}_{\mathrm{IIC}}$ and $\mathrm{K}_{\text {IIIC }}$ are the fracture toughness of three modes equal to 116.6, 116.6 and 67.27 $\mathrm{MPa} \sqrt{ } \mathrm{m}$ respectively for API X52 pipe steel. In steel;

$$
K_{I C}=K_{I I C}
$$

And where the equation of calculation $\mathrm{K}_{\mathrm{IIIC}}$ is given by as follow

$$
k_{\text {IIIC }}=\frac{\tau_{C}}{\sigma_{C}} K_{I I C}
$$

where $\tau_{\mathrm{c}}$ and $\sigma_{\mathrm{c}}$ are critical shear and normal stresses.

Fig. 15 gives an evolution of fracture condition $\mathrm{C}$ for different crack orientations under the same internal pressure and for a relative crack depth $\mathrm{a} / \mathrm{t}=0.5$.

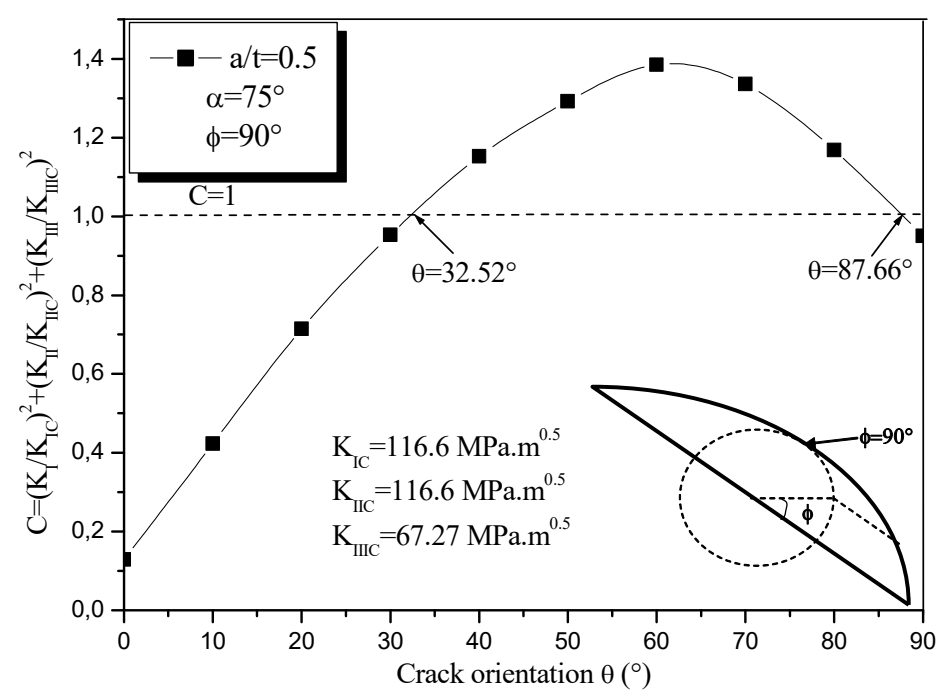

Figure 15: Evaluation of fracture condition equation with crack orientation $C=f(\theta)$

Fracture condition is fulfilled for crack orientation in the value range of $\theta$ from $32.52^{\circ}$ to $87.66^{\circ}$ for semi-elliptical crack front position $\left(\phi=90^{\circ}\right)$.

\section{Particular FAilure Assessment Diagram (FAD)USE FOr Elbow CRACK DEFECT}

$\mathrm{I}$ $\mathrm{n}$ order to analyze the behavior of elbows failure the task of Failure Assessment Diagram was focused on the determination of stress intensity factors which was examined depending the critical crack depth ratios at a critical position and a critical angle. In the case that the stress intensity factors was not enough to show the critical zones along the propagation of the cracks in the elbow, the FAD becomes a necessary step to predict the crack zones depending on three zones: the security zone, the safety zone, and the failure zone.

The assessment of elbow defect harmfulness is made using Failure Assessment Diagram (FAD). FAD presents defect loading conditions in a graph where the non-dimensional crack driving force $\mathrm{k}_{\mathrm{r}}$ is plotted versus non-dimensional applied stress $L_{r}$. Due to a mixed mode loading, the non-dimensional crack driving force $k_{r}$ is defined as the ratio of maximum equivalent stress intensity factor, $K_{\text {eq,max }}$, to the fracture toughness of material in mode $\mathrm{K}_{\mathrm{IC}}$.

$$
\mathrm{k}_{\mathrm{r}}=\mathrm{K}_{\mathrm{eq}} / \mathrm{K}_{\mathrm{Ic}}
$$

Here in this particular FAD Non-dimensional load $L_{r}$ is defined as the ratio of maximum circumferential stress $\sigma_{\theta \theta}$,max and flow stress $\sigma_{\mathrm{o}}$ : 


$$
\mathrm{L}_{\mathrm{r}}=\sigma_{\theta \theta \text { max }} / \sigma_{0}
$$

with

$$
\sigma_{0}=\sigma_{y}+\sigma_{u l} / 2
$$

$\sigma_{\mathrm{y}}$ is the yield stress, $\sigma_{\mathrm{ult}}$ the ultimate stress. In FAD, failure is given by the following condition; if the assessment point of coordinate $\left[L_{r}^{*}, k_{r}^{*}\right]$ is under the failure curve given by the following equation $k_{r, c}=f\left(L_{r, c}\right)$ where the subscript c indicates critical condition, the structure is safe. If the assessment point is above the curve, failure occurs.

Fig. 16 represents the Failure Assessment Diagram for elbow and straight pipe for different value of relative depth crack ratio $(\mathrm{a} / \mathrm{t})$ in the range $0.1-0.8$.

Values of fracture toughness take into account the constraint effect [29, 37]. Constraint is defined by $T$ stress [38] and determined by the Stress Difference Method [39, 40]. Material Failure Master Curve (MFMC) expressed the dependence of fracture toughness with effective critical constrain $T_{e f, c}$. For pipe steel, MFMC has been determined by Eqn. 9 where it obeys a linear relationship

$$
k_{\text {IC }}=a T_{e f, C}+K_{I C, 0}
$$

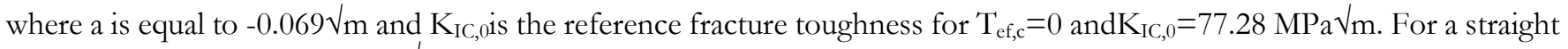
pipe, a value of $\mathrm{K}_{\mathrm{IC}}=116.6 \mathrm{Mpa} \sqrt{\mathrm{m}}_{\mathrm{m}}$ was obtained and corresponds to a low constrain which has generally encountered in a pipe submitted to internal pressure. For elbow, the value of fracture toughness was reduced to $\mathrm{K}_{\mathrm{IC}, 0}=95 \mathrm{Mpa} \bigvee_{\mathrm{m}}$ due to a higher constrain. Evolutions of assessment points for different relative crack depth ratios are reported in FAD for straight pipe and elbow with same pressure, diameter and thickness in Fig. 16. It is noted that due to stress amplification and higher constrain, the assessment points for the same defect size is located with higher ordinates. Critical defect sizes are defined when evolution curves cross the failure curve. For elbow, the relative critical defect depth is $(a / t=0.28)$, which is higher for a straight pipe $(\mathrm{a} / \mathrm{t}=0.66)$. Assessment points for elbow and below failure are located in the brittle zone of the FAD. This is proving the use of a linear behavior for computing SIF. This assumption is not valid for a straight pipe but it is given here for comparison.

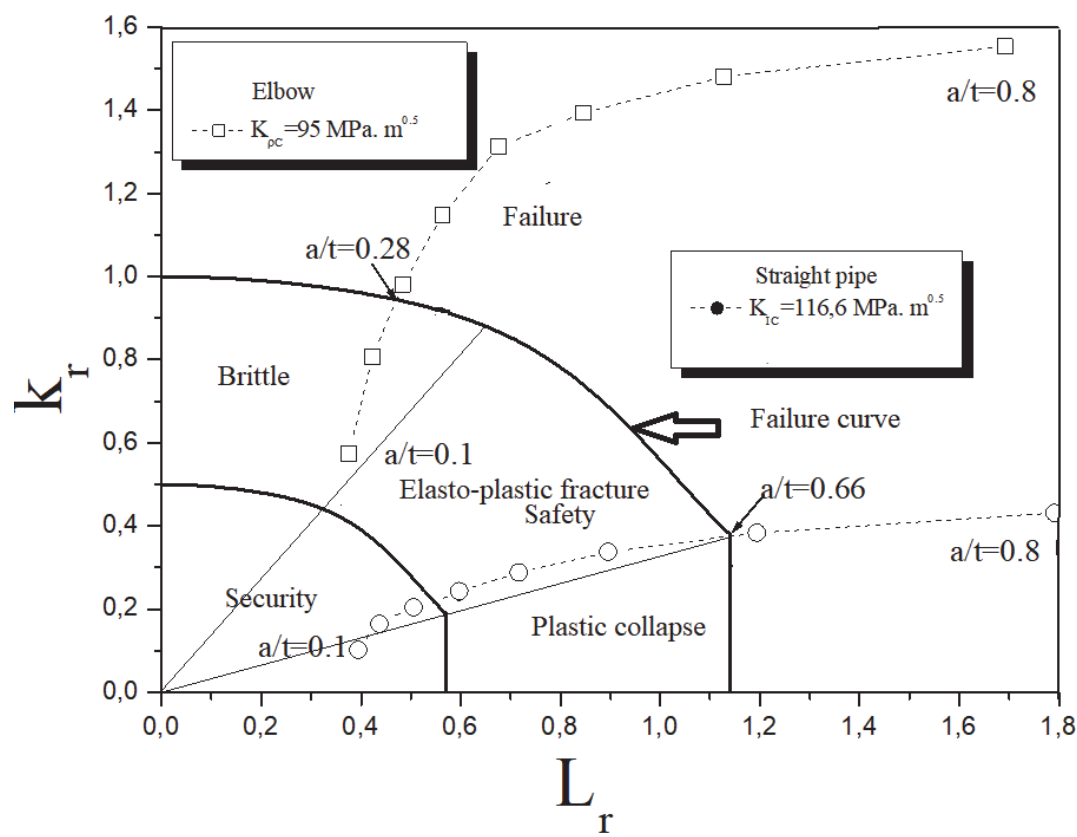

Figure 16: Failure Assessment Diagram for straight pipe and elbow Evolution of assessment points with relative crack depth $(\mathrm{a} / \mathrm{t}=0.1$ $-0.8)$ and $\left(\mathrm{K}_{\mathrm{IC}}=95\right.$ and $\left.116.6 \mathrm{Mpa} \cdot \mathrm{m}^{0.5}\right)$ 


\section{CONCLUSION}

he presence of elbow in piping system leads to activate a locally stresses. For the studied pipe (internal radius $\mathrm{R}_{\mathrm{i}}=$ $298.45 \mathrm{~mm}$, wall thickness $\mathrm{t}=12.7 \mathrm{~mm}$ ) and for internal pressure $\mathrm{P}=7 \mathrm{MPa}$, stress amplification factor $\mathrm{k}_{\mathrm{t}}$ was found to be 1.2. The maximum stress was located at a curvature angle $\alpha=72^{\circ}$. This localized an eventual defect which is considered as a semi-0elliptical surface defect. This defect is submitted to mixed mode of loading due to longitudinal and circumferential pipe stress distribution and elbow and pipe curvature. The mixed mode consists of superposition of mode I, II and III. Therefore, an equivalent stress intensity factor was computed and a mixed mode failure criterion was used to determine critical semi elliptical crack orientation. The assessment of defects in elbow can be made with a modified Failure Assessment Diagram where the non-dimensional crack driving force refers to the equivalent stress intensity factor and the value of fracture toughness which take into account high constrain in elbow. Severe stress conditions of a defect in elbow locate its assessment point in the brittle part of the FAD.

\section{REFERENCES}

[1] Meriem-Benziane, M., Abdul-Wahab, S.A., Benaicha, M. and Belhadri, M., 2012. Investigating the rheological properties of light crude oil and the characteristics of its emulsions in order to improve pipeline flow. Fuel, 95, pp.97-107. DOI: $10.1016 /$ j.fuel.2011.10.007.

[2] Meriem-Benziane, M. and Zahloul, H., 2013. Rheological Behaviors of Crude Oil in the Presence of Water. Int J Mech Aerospace Mech Eng, 7, pp.223-227, DOI: 10.5281/zenodo.1329577.

[3] Testa, G., Bonora, N., Gentile, D., Ruggiero, A., Iannitti, G., Carlucci, A., Madi, Y., (2017), Strain capacity assessment of API X65 steel using damage mechanics, Frattura ed Integrità Strutturale, 42 (2017) 315-327. DOI: $10.3221 /$ IGF-ESIS.42.33.

[4] Larrosa, N.O., Ainsworth, R.A., (2016), Ductile fracture modelling and J-Q fracture mechanics: a constraint based fracture assessment approach, Frattura ed Integrità Strutturale, 10(38), pp. 266-272, DOI: 10.3221/IGF-ESIS.38.36.

[5] Ouardi, A., Majid, F., Mouhib, N., Elghorba, M., (2018), Residual life prediction of defected Polypropylene Random copolymer pipes (PPR), Frattura ed Integrità Strutturale, 43, pp. 97-105, DOI: 10.3221/IGF-ESIS.43.07.

[6] Vazouras, P., Karamanos, SA., (2017), Structural behavior of buried pipe bends and their effect on pipeline response in fault crossing areas, Bull Earthq Eng, DOI: 10.1007/s10518-017-0148-0.

[7] Karamanos, SA., (2016), Mechanical behavior of steel pipe bends: an overview, J Press Vessel Technol 138, 41203, DOI: $10.1115 / 1.4031940$.

[8] Soudani, M., Bouledroua, O., Hadj Meliani, M., El-miloudi, K., Muthanna, B.G.N., Khelil, A., Elhoud, A., Matvienko, Y.G. and Pluvinage, G., (2018). Corrosion inspection and recommendation on the internal wall degradation caused rupture of 6" gas line pipe. Journal of Bio-and Tribo-Corrosion, 4(2), p.28, DOI: 10.1007/s40735-018-0145-0.

[9] Hadj Meliani, M., Bouledroua, O., Azari, Z., Sorour, A., Merah, N. and Pluvinage, G., (2017). The inspections, standards and repairing methods for pipeline with composite: a review and case study. In International Conference on New Trends in Fatigue and Fracture (pp. 147-156). Springer, Cham, DOI: 10.1007/978-3-319-70365-7_17.

[10] Meriem Meriem-Benziane, M., Bou-Saï, B. and Boudouani, N., (2017). The effect of crude oil in the pipeline corrosion by the naphthenic acid and the sulfur: A numerical approach. Journal of Petroleum Science and Engineering, 158, pp.672-679. DOI: 10.1016/j.petrol.2017.08.073.

[11] Soudani, M., Hadj Meliani, M., El-Miloudi, K., Bouledroua, O., Fares, C., Benghalia, M.A., Azari, Z., Capelle, J., Sorour, A.A. and Pluvinage, G., (2018). Efficiency of green inhibitors against hydrogen embrittlement on mechanical properties of pipe steel API 5L X52 in hydrochloric acid medium. Journal of Bio-and Tribo-Corrosion, 4(3), p.36. DOI: $10.1007 / \mathrm{s} 40735-018-0153-0$.

[12] Liu, J.G., Bakedashi, W., Li, Z., Xu, Y.Z., Ji, W.R., Zhang, C., Cui, G., Zhang, R.Y., (2017), Effect of flow velocity on erosion-corrosion of 90- degree horizontal elbow, Wear DOI: 10.1016/j.wear.2016.11.015.

[13] Zeng, L., Shuang, S., Guo, X.P., Zhang, G.A., (2016), Erosion-corrosion of stainless steel at different locations of a $90^{\circ}$ elbow, Corros. Sci. 111, pp. 72, DOI: 10.1016/j.corsci.2016.05.004.

[14] Borruto, A., Narducci, G., Pietrosanti, P., (2012), Analysis of the causes of failure in 5Cr-1Mo pipes mounted in a preheating furnace, Frattura ed Integrità Strutturale, 20, pp. 22-31, DOI: 10.3221/IGF-ESIS.20.03.

[15] Amara, M., Muthanna, B.G.N., Abbes, M.T. and Hadj Meliani, M., 2018. Effect of sand particles on the Erosioncorrosion for a different locations of carbon steel pipe elbow. Procedia Structural Integrity, 13, pp. 2137-2142, 
DOI: $10.1016 /$ j.prostr.2018.12.151.

[16] El-Gammal, M., Mazhar, H., Cotton, J. S., Shefski, C., Pietralik, J., Ching, C. Y., (2010), The Hydrodynamic Effects of Single-phase Flow on Flow Accelerated Corrosion in a 90-degree elbow, Nuclear Engineering and Design, Vol. 240, pp.1589-1598. DOI: 10.1016/j.nucengdes.2009.12.005.

[17] Muthanna, B.G.N., Amara, M., Hadj Meliani, M., Mettai, B., Božić, Z., Suleiman, R., Sorour, A.A., (in press), Inspection of internal erosion-corrosion of elbow pipe in the desalination station, Engineering Failure Analysis, DOI: $10.1016 /$ j.engfailanal.2019.04.062.

[18] Tian, J., Huang, H.L., Pan, Z.Q., Zhou, H., (2016), Effect of flow velocity on corrosion behavior of AZ91D magnesium alloy at elbow of loop system, Trans. Nonferrous Met. Soc. China 26, pp. 2857-2867.

DOI: 10.1016/S1003-6326(16)64414-X.

[19] Bouledroua, O., Hadj Meliani, M., Azari, Z., Sorour, A., Merah, N. and Pluvinage, G., 2017. Effect of sandblasting on tensile properties, hardness and fracture resistance of a line pipe steel used in algeria for oil transport. Journal of Failure Analysis and Prevention, 17(5), pp.890-904, DOI: 10.1007/s11668-017-0313-4.

[20] Siamack, A., Shirazi, Brenton S. Mclaury, John R. Shadley, Kenneth P. Roberts, Edmund F. Rybicki, Hernan E. Rincon, ShokrollahHassani, Faisal M. Al-mutahar, and Gusai H. Al-Aithan, (2015), Erosion-Corrosion in Oil and Gas Pipelines, Library of Congress Cataloging-in-Publication Data applied for., 2015, DOI: 10.1002/9781119019213.ch28.

[21] Soudani, M., Hadj Meliani, M., El-Miloudi, K., Azari, Z., Sorour, A.A., Merah, N. and Pluvinage, G., 2018. Reduction of hydrogen embrittlement of API 51 X65 steel pipe using a green inhibitor. International Journal of Hydrogen Energy, 43(24), pp.11150-11159, DOI: 10.1016/j.ijhydene.2018.04.236.

[22] de Barros, S., Budhe, S., Banea, M.D., Rohem, N.R.F., Sampaio, E.M., Perrut, V.A., Lana, L.D.M., (2018), An assessment of composite repair system in offshore platform for corroded circumferential welds in super duplex steel pipe, Frattura ed Integrità Strutturale, 44, pp. 151-160, DOI: 10.3221/IGF-ESIS.44.12.

[23] Zhang, S.H., Gao, C.R., Zhao, D.W. and Wang, G.D., 2013. Limit analysis of defect-free pipe elbow under internal pressure with mean yield criterion. Journal of Iron and Steel Research, International, 20(4), pp.11-15, DOI: 10.1016/S1006-706X(13)60075-8.

[24] Li, Z., Yinpei, W., Jin, C. and Cengdian, L., 2001. Evaluation of local thinned pressurized elbows. International journal of pressure vessels and piping, 78(10), pp.697-703, DOI: 10.1016/S0308-0161(01)00125-9.

[25] Kim, J.W., Na, Y.S. and Lee, S.H., 2009. Experimental evaluation of the bending load effect on the failure pressure of wall-thinned elbows. Journal of Pressure Vessel Technology, 131(3), p.031210.

[26] Zhang, S.H., Chen, X.D., Wang, X.N. and Hou, J.X., 2015. Modeling of burst pressure for internal pressurized pipe elbow considering the effect of yield to tensile strength ratio. Meccanica, 50(8), pp.2123-2133,

DOI: 10.1007/s11012-015-0148-6.

[27] Boukortt, H., Amara, M., Hadj Meliani, M., Bouledroua, O., Muthanna, B.G.N., Suleiman, R.K., Sorour, A.A. and Pluvinage, G., 2018. Hydrogen embrittlement effect on the structural integrity of API 5L X52 steel pipeline. International Journal of Hydrogen Energy, 43(42), pp.19615-19624, DOI: 10.1016/j.ijhydene.2018.08.149.

[28] Meriem-Benziane, M., Abdul-Wahab, S. A., Zahloul, H., Babaziane, B., HadjMeliani, M., and Pluvinage, G., (2015), Finite Element Analysis of the Integrity of an API X65 Pipeline With a Longitudinal Crack Repaired With Single- and Double-Bonded Composites, Composites, Part B, 77(8), pp. 431-439, DOI: 10.1016/j.compositesb.2015.03.008.

[29] Bouledroua, O., Hadj Meliani, M. and Pluvinage, G., 2017. Assessment of pipe defects using a constraint-modified failure assessment diagram. Journal of Failure Analysis and Prevention, 17(1), pp.144-153, DOI: $10.1007 / \mathrm{s} 11668-016-0221-\mathrm{z}$.

[30] Pluvinage, G., Bouledroua, O., Hadj Meliani, M., Suleiman Rami, K., (2018), Corrosion defect analysis using domain failure assessment diagram, Int J Pres. Ves. Pip., 165, 126e34, DOI: 10.1016/j.ijpvp.2018.06.005.

[31] Bouledroua, O., Zelmati, D. and Hassani, M., 2019. Inspections, statistical and reliability assessment study of corroded pipeline. Engineering Failure Analysis, 100, pp.1-10, DOI: 10.1016/j.engfailanal.2019.02.012.

[32] https://www.ansys.com/products.

[33] Raju, I.S. and Newman Jr, J.C., 1979. Stress-intensity factors for a wide range of semi-elliptical surface cracks in finitethickness plates. Engineering fracture mechanics, 11(4), pp.817-829.

[34] Newman Jr, J.C. and Raju, I.S., 1981. An empirical stress-intensity factor equation for the surface crack. Engineering fracture mechanics, 15(1-2), pp.185-192.

[35] Mattheck, C., Munz, D. and Stamm, H., 1983. Stress intensity factor for semi-elliptical surface cracks loaded by stress gradients. Engineering fracture mechanics, 18(3), pp.633-641.

[36] Hadj Meliani, M., Matvienko, Y.G. and Pluvinage, G., 2011. Two-parameter fracture criterion (K @, c-T ef, c) based on notch fracture mechanics. International Journal of Fracture, 167(2), pp.173-182. 
[37] Amara, M., Bouledroua, O., Hadj Meliani, M., Muthanna, B.G.N., Tahar Abbes, M., Pluvinage, G., (2018), Assessment of pipe for $\mathrm{CO}_{2}$ transportation using a constraint modified CTOD failure assessment diagram, Structural integrity and life, 18(2), pp. 149-153

[38] Bouledroua, O., Hadj Meliani, M. and Pluvinage, G., (2016). A review of T-stress calculation methods in fracture mechanics computation. Nature \& Technology, (15), p.20.

[39] Elazzizi, A., Hadj Meliani, M., Khelil, A., Pluvinage, G., Matvienko, Y.G., (2015), The master failure curve of pipe steels and crack paths in connection with hydrogen embrittlement, International Journal of Hydrogen Energy. 40(5), pp. 2295-2302, DOI: 10.1016/j.ijhydene.2014.12.040.

[40] Hadj Meliani, M., Azari, Z., Al-Qadhi, M., Merah, N. and Pluvinage, G., 2015. A two-parameter approach to assessing notch fracture behaviour in clay/epoxy nanocomposites. Composites Part B: Engineering, 80, pp.126-133, DOI: $10.1016 /$ j.compositesb.2015.05.034. 